\title{
Microtextural investigation (SEM and TEM study) of phyllosilicates in a major thrust fault zone (Monte Perdido, southern Pyrenees): impact on fault reactivation
}

\author{
Martine D. Buatier - Brice Lacroix • Pierre Labaume - Virginie Moutarlier • \\ Delphine Charpentier · Jean Pierre Sizun · Anna Travé
}

Received: 9 August 2011/Accepted: 20 April 2012/Published online: 18 August 2012

(C) Swiss Geological Society 2012

\begin{abstract}
Thrusting fault zone in foreland basins are characterized by highly foliated zones generally enriched in phyllosilicates which can play a major role on the mechanical behaviour of the fault. In this context, investigations of synkinematic clay minerals permit to determine the origin of the fluid from which they precipitated as well as the mechanisms of deformation. Our study is focused on clay mineral assemblages (illite and chlorite) in a major thrust fault located in the Monte Perdido massif (southern Pyrenees), a shallow thrust that affects upper cretaceouspaleocene platform carbonates and lower Eocene marls and turbidites. It implied $3 \mathrm{~km}$ of displacement of the Monte Perdido thrust unit with respect to the underlying Gavarnie unit. In this area the cleavage development by pressuresolution is linked to the Monte Perdido and Gavarnie thrust
\end{abstract}

Editorial handling: Rafael Ferreiro Mählmann and Edwin Gnos.

M. D. Buatier $(\bowtie) \cdot$ D. Charpentier · J. P. Sizun

Laboratoire ChronoEnvironnement, Université de Franche

Comté, 16 route de Gray, 25030 Besançon, France

e-mail: martine.buatier@univ-fcomte.fr

B. Lacroix

Institut de Minéralogie et Géochimie, Université de Lausanne,

1015 Lausanne, Switzerland

P. Labaume

Géosciences Montpellier, UMR 5243, Université Montpellier 2, 34095 Montpellier, France

V. Moutarlier

Lab. UTINAM, Université de Franche Comté, 16 route de Gray, 25030 Besançon, France

A. Travé

Departament de Geoquímica, Petrologia i Prospecció Geològica, Facultat de Geologia, Universitat de Barcelona, 08028

Barcelona, Spain activity. The core zone of the fault, about $6 \mathrm{~m}$ thick, consists of an interval of intensely deformed clay-bearing rocks bounded by major shear surfaces. The deformed sediment is markedly darker than the protolith. Calcitequartz shear veins along the shear planes are abundant. Detailed SEM and TEM observations of highly deformed fault zone samples indicate that clay mineral enrichment in the core zone of the fault is not only related to passive increase by pressure-solution mechanism but that dissolution-recrystallization of phyllosilicates occurs during deformation. A mineral segregation is observed in the highly deformed zone. Newly formed $2 M_{1}$ muscovite is present along the cleavage whereas $I I b$ chlorite crystals fill $\mathrm{S}_{\mathrm{V}} 2$ shear veins suggesting syntectonic growth of phyllosilicates in the presence of fluids in low-grade metamorphic conditions. These mineralogical reactions act as weakening processes and would favour Monte Perdido fault creeping.

Keywords Thrust fault - Clay minerals - TEM · Slip weakening $\cdot$ Deformation $\cdot$ Sediments

\section{Introduction}

Clay minerals are ubiquist minerals in fault zones. They represent an important parameter that can control the fault deformation processes. Consequently, the motion mechanisms along major faults can be largely influenced by the presence of clay minerals (Rutter et al. 1986, Vrolijk and Van der Pluijm 1999; Van der Pluijm 2011). The low friction coefficient characterizing clay minerals favours the slip weakening through steady aseismic creeping deformation (Morrow et al., 2000; Collettini et al. 2009). Experimental investigation have shown that weak gouges, generally enriched in clay minerals, with coefficients of 
friction $\mu<0.5$, exhibit stable sliding behaviour (e.g. Takahashi et al. 2007; Ikari et al. 2011). In the San Andrea fault observatory at depth (SAFOD) core samples, the weakening of the San Andreas fault zone down to depths of at least $3 \mathrm{~km}$ is attributed to the pervasive development of interconnected networks of low friction smectitic phyllosilicates and to the operation of stress-induced solutionprecipitation creep mechanisms (Holdsworth et al. 2011; Gratier et al. 2011).

Morrow et al. (2000) have demonstrated that the frictional strength of clay minerals is inversely dependant on their capacity to adsorb water and therefore, may influence fault behaviour. Frictional heating of clayey gouges may also produce mineral reactions and water release and contribute to pressurization of pore fluids (Sibson 1973; Kameda et al. 2011a, b). In aseismic creeping fault, deformation gives rise to textural rearrangement of clay particles (e.g. Buatier et al. 2012) and/or dissolution-precipitation mechanisms, both mechanisms being particularly important in the fault strength reduction (Wintsch et al. 1995; Vrolijk and van der Pluijm 1999; Smith and Faulkner 2010). The softening effect of rearrangement of clays was also observed in the Zuccale fault by Viti and Colettini
(2009) who described growth and deformation of talc in this fault zone.

In thrust faults from thrust-and-fold belts, gouges are generally rare but the core zone of the fault can be enriched in clay minerals (Lacroix et al. 2011). In these structures the major deformation process is pressure-solution allowing for an increase of the supposed insoluble clay minerals. However, because of their very small size, investigations of the clay microstructures are not possible at the optical microscopic scale and the behaviour of clay minerals is still unclear. Clay minerals can be re-oriented passively during deformation or affected by dissolution-precipitation process.

In the present study we examine the nature and the textural arrangement of clay minerals in a major thrust fault zone (Monte Perdido thrust fault, southern Pyrenees; Fig. 1) formed in low grade metamorphic conditions and related to the thrust activity using scanning electron and transmission electron microscope techniques. The aim of the study is to establish the origin of the clay minerals in a major thrust fault affecting sedimentary rocks, to understand their behaviour during deformation and finally to discuss their influence on fault activity.
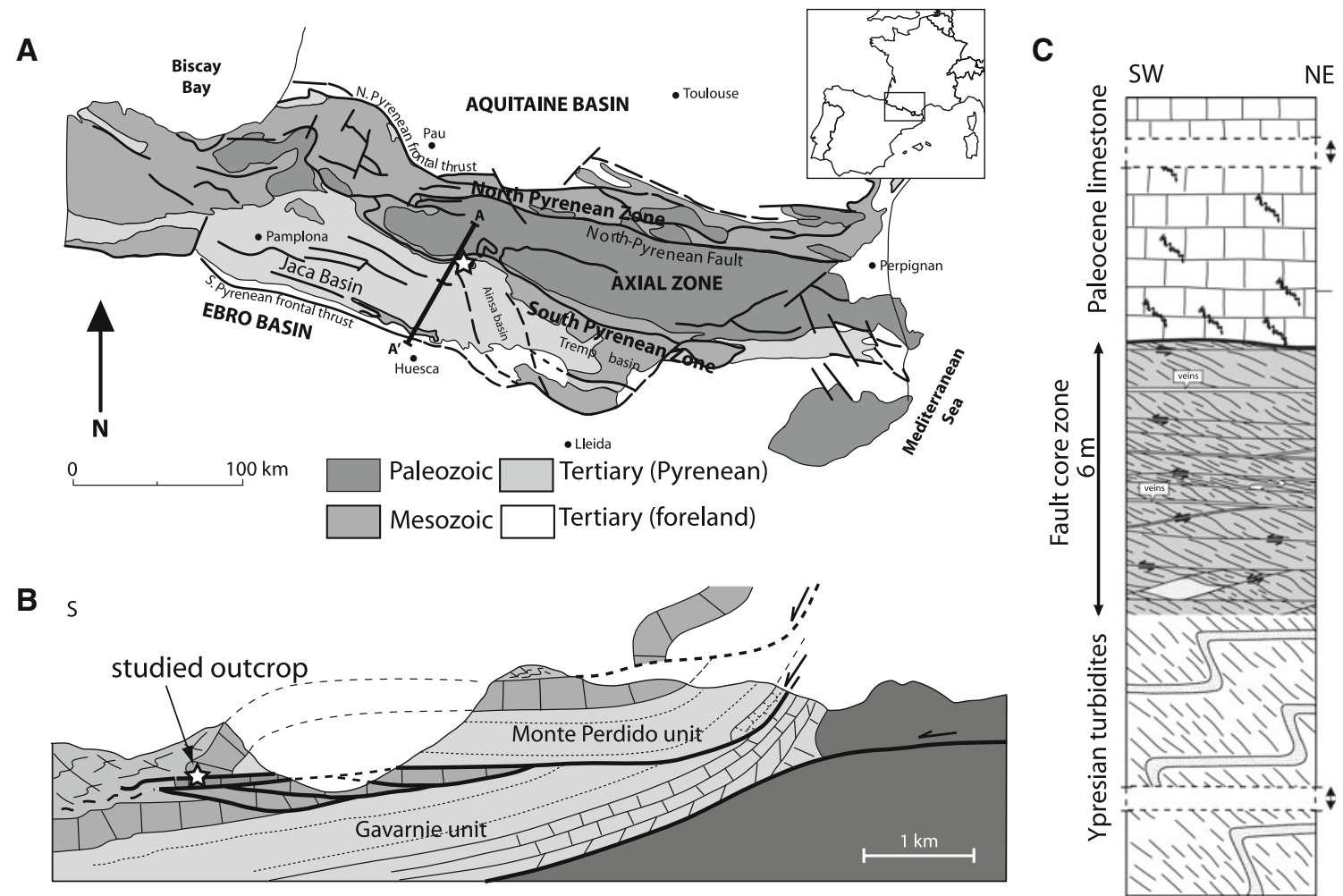

Fig. 1 Location of the studied thrust fault and structural organization of the fault zone (modified from Lacroix et al. 2011). a Location of the Torla outcrop on the Monte Perdido thrust fault in the southPyrenean foreland basin (Jaca basin). b Schematic North-South cross section of the northern edge of the Jaca basin showing the imbrication of the Gavarnie and Monte Perdido thrust units. The studied outcrop is indicated. c stratigraphy and structures of the studied fault zone and adjacent hanging wall and foot-wall 


\section{Geological setting and outcrop description}

The Pyrenees represent an orogenic wedge formed during convergence between Iberia and Europe from Late Cretaceous to Early Miocene, in relation to the northward continental subduction of the Iberian lithosphere (e.g. Choukroune et al. 1990; Muñoz 1992; Teixell, 1998; Beaumont et al. 2000). From the North to the South, three main structural zones constitute the Pyrenean orogen (Fig. 1a). The North-Pyrenean zone corresponds to a Mesozoic extensional basin inverted and transported northward by the Pyrenean compression. The axial zone corresponds to the inner part of the south-vergent thrust belt and consists of Paleozoic rocks deformed and metamorphosed during the Hercynian orogeny, locally cross-cut by Late Hercynian granitoid intrusions and covered by Permo-Triasic sediments. The southern belt corresponds to the imbrications of south-verging cover thrust units rooted in the axial zone Paleozoic basement.

In the western part of the South-Pyrenean Zone (Fig. 1a), the Jaca thrust-sheet-top basin comprises Cenomanian to Santonian platform limestones covered by the upper Cretaceous-Paleogene syn-orogenic succession with, from bottom to top, Campanian to earliest Eocene platform carbonates, the Ypresan- Lutetian siliciclastic turbidites of the Hecho Group and Bartonian to Lower Oligocene coastal and continental deposits (e.g. Teixell 1996; Fig. 1b).

The present study focuses on the Monte Perdido thrust fault which is located in the northern part of the Jaca Basin (Fig. 1b). The Monte Perdido thrust activity is dated to the latest Lutetian to earliest Priabonian (about 47-37 Ma; Teixell 1996). The Monte Perdido thrust unit was uplifted and folded by the emplacement of the underlying Gavarnie thrust unit (Fig. 1c). It is affected by a regional pressure solution cleavage (Séguret 1972; Labaume et al. 1985; Teixell 1996; Oliva-Urcia et al. 2009) formed coeval to decametric to hectometric folds related to the Monte Perdido and Gavarnie thrust activity.

A selected outcrop (Torla; Figs. 1c, 2) related to the Monte Perdido thrust was studied and sampled (see also Lacroix et al. 2011, 2012). The hanging wall comprises the Alveolina limestone of the Monte Perdido thrust unit and the footwall comprises Hecho Group turbidites (alternating sandstone and pelite layers) of the Gavarnie thrust unit.

The fault core zone, about $6 \mathrm{~m}$ thick, consists of an interval of intensely deformed clay rich sediments bounded by two major upper and lower shear surfaces (Figs. 1c, 2). The presence of sandstone lenses allows the identification of the footwall turbidites as the protolith of the fault rock. However, the deformed sediments are markedly darker than the protolith turbidites (Fig. 2b).
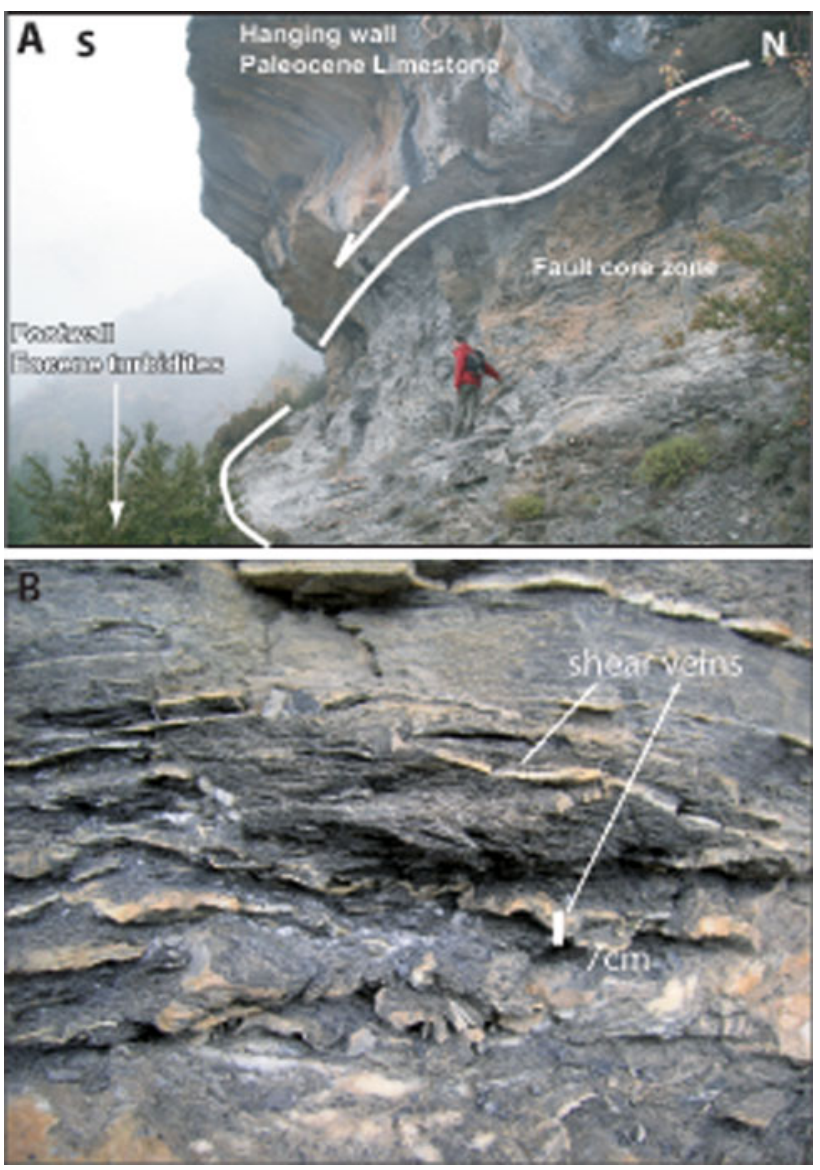

Fig. 2 The Monte Perdido fault zone at Torla: general view of the studied outcrop (a) and a closer view of the typical structures of the highly deformed core zone (b). In the core zone, the clay-rich sediment is intensely foliated and dark in color. It contains calcite and quartz shear veins affected by late folding

\section{Summary of previous studies}

The macro and microstructures related to the Monte Perdido thrust fault were studied by Lacroix et al. (2011). At the macroscopic scale, the deformation of the clay-rich sediments in the fault core zone is marked by the combination of intense cleavage and shear surfaces forming Shear-Cleavage (S-C) networks. Calcite-quartz shear veins along the shear planes are abundant (Fig. 2b). The cleavage orientation, the asymmetry of $\mathrm{S}-\mathrm{C}$ structures and steps along shear vein striations all indicate a top to the S-SW displacement $\left(\mathrm{N} 315^{\circ} \mathrm{E}\right)$.

Although deformation principally occurs in the core zone, it also affects the hanging wall and footwall. In the hanging wall Alveolina limestone, the deformation is principally marked by stylolites and calcite extension veins. The footwall turbidites are deformed by $\mathrm{cm}$ - to $\mathrm{m}$-scale asymmetric, south-vergent folds with north-dipping axial plane cleavage. Calcite extension veins are also present and crosscut the cleavage. The main $\mathrm{N} 315^{\circ} \mathrm{E}$ 
orientation of cleavage outside the fault zone is similar to that measured in the fault zones. All kinematic markers thus indicate a tectonic transport toward the S-SW, subperpendicular to the regional N120 structural trend (Séguret 1972).

At the microscopic scale, the cleavage in the highly deformed core zone appears to be a pressure-solution cleavage featuring a $\mathrm{S}-\mathrm{C}$ structure and associated to several generations of veins described in detail in Lacroix et al. (2011). The first generation corresponds to shear veins $\left(S_{V} 1\right)$ and extension veins $\left(E_{V} 1\right)$ filled by calcite and subsidiary quartz which formed coevally to the pressure solution cleavage during the main shearing episode. These structures were affected by a second stage of shear deformation comprising microfolding and the formation of two types of veins: the $E_{\mathrm{V}} 2$ calcite-quartz extension veins and the $S_{\mathrm{V}} 2$ chlorite shear veins. A late stage of deformation is marked by the $\mathrm{E}_{\mathrm{V}} 3$ calcite extension veins corresponding to a network of irregular fractures filled with blocky to elongated calcite crystals. The latter structures are related to the late exhumation of the massif.

Lacroix et al. $(2011,2012)$ demonstrated that the first stage of deformation, related to the Monte Perdido thrust unit emplacement, occurred at a temperature around $210{ }^{\circ} \mathrm{C}$ and a burial depth of about $6 \mathrm{~km}$ (estimated from calcite to quartz $\delta^{18} \mathrm{O}$ values and microthermometry of fluid inclusion). The second deformation episode corresponds to a fault reactivation associated to the development of the chlorite shear veins in highly foliated clay-rich core zone. Coupling compositional chlorite geothermometry with fluid inclusion microthermometry, Lacroix et al. (2012) estimated a temperature of $240{ }^{\circ} \mathrm{C}$ and a burial depth of about $7 \mathrm{~km}$ for this second stage of deformation. The O-isotope fractionation between cogenetic chlorite and quartz gives a similar range of temperatures (234 to $265^{\circ} \mathrm{C}$ ). These temperature-burial conditions are consistent with a geothermal gradient of $34{ }^{\circ} \mathrm{C} / \mathrm{km}$.

In the present study we focus on the highly deformed clay-rich sediments from the Monte Perdido thrust core zone. The SEM-BSE and TEM images coupled with XRD and SAED diffraction analyses are used to determine the nature of clay minerals and to precise their behaviour during deformation processes.

\section{Methods}

\subsection{Mineralogical identification (XRD)}

X-ray diffraction analyses were performed on bulk samples and on $<2 \mu \mathrm{m}$ fractions powders on a Bruker-AXS D8 Advance diffractometer with $\mathrm{Cu} \mathrm{K} \alpha$ radiation $(40 \mathrm{~mA}$, $40 \mathrm{kV}$ ), Ni K $\beta$ filter and a LynEye position sensitive detector (PSD). Spectra were acquired from $4^{\circ}$ to $65^{\circ} 2 \theta$, at steps of $0.01 \%$ s. The identification of all minerals was done with Bruker's DiffracPlus EVA software and PDF-2 database (ICDD, 2008). The b cell-parameter of illite was calculated from the (060) reflexion measured on the $<2 \mu \mathrm{m}$ fractions. Rietveld quantification was performed on the $<2 \mu \mathrm{m}$ fraction (powders) using Bruker's TOPAS software, in the appropriated zone from $28^{\circ}$ to $45^{\circ} 2 \theta$. Indeed, this zone was chosen because it does npt contain the (001) peaks sensitive to phyllosilicate preferred orientation that would necessitate a more delicate refinement. The quantitative phase analysis consisted of fitting a calculated X-ray diffractogram to the experimental diffractogram and minimizing the difference between them. The difference between measured and calculated curve corresponded to the residual weighted profile (Rwp) factor, which has to be lowest.

The calculated X-ray diffractogram was obtained from the crystal structure of each phase and from the geometrical parameters of the diffractometer. Crystal structure informations of each phase (clinochlore, muscovite $1 M$ and muscovite $2 M_{1}$ ) were downloaded from the Bruker Structure Database.

\subsection{Sample preparation, SEM and TEM analyses}

Polished thin sections of samples from the highly deformed fault core zone were carbon coated and examined on a Jeol 5600 SEM equipped with a Fondis EDS detector at the Centre Commun de Microscopie of Université de Franche Comté in Besançon. The SEM was operated with an accelerating voltage of $20 \mathrm{kV}$. SEM micrographs were collected in both secondary electron and backscattered electron modes. The samples were also analyzed for mineralogical composition with the EDS Fondis detector.

For TEM observations, selected samples from thin sections were mounted on $\mathrm{Cu}$ grids and thinned with a Gatan Argon ion mill and carbon coated. TEM observations were made with a Jeol 2000FX microscope operating at $200 \mathrm{kV}$ at the Center of Analysis (ARCEN) of the University of Bourgogne (Dijon).

\section{Results}

\subsection{Mineralogical characterization}

The XRD patterns of the bulk sediments of two representative samples from the hanging wall host rock (pelite, HR) and the highly deformed fault core zone (HDZ) are presented in Fig. 3. It can be noticed that the quartz reflections display similar intensities in both diagram, whereas calcite, which is the major constituent of the host sediment, is the less abundant 

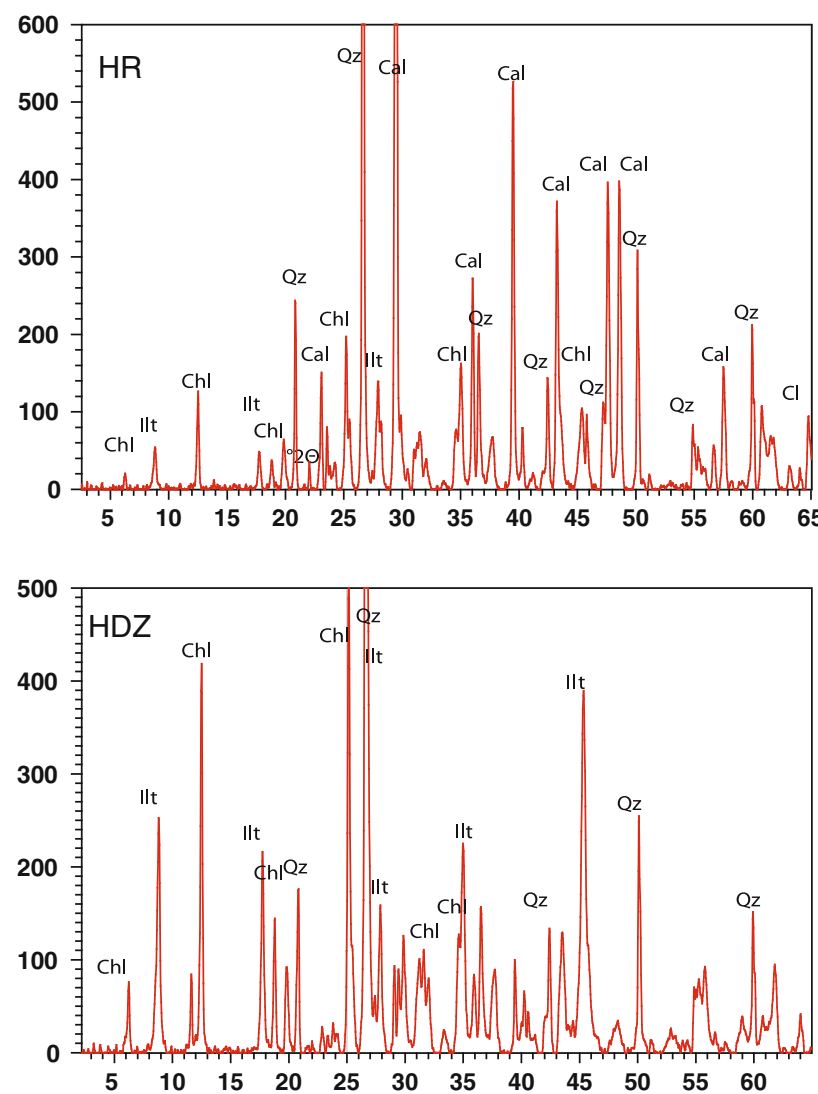

Fig. 3 XRD patterns of bulk samples from the host rock (HR) and from the highly deformed zone (HDZ) in the fault core. $C h l$ chlorite, Ilt Illite, $Q z$ quartz, Cal calcite

phase in the sample from the core zone. The phyllosilicate composition is similar in both samples with both illite and chlorite reflections being more intense in the core zone sample (HDZ) than in the host rock sample (HR). These data suggest an increase of phyllosilicates relative abundance in fault core zone compared to the host sediment, which could be attributed to calcite and partial quartz departure by pressure solution during deformation in the fault core zone.

The XRD patterns of the $<2 \mu \mathrm{m}$ fraction powders are very similar for samples from the host rock and the highly deformed zone. Illite and chlorite (clinochlore) are the two principal phases in the clay fraction but the main quartz peaks are also present in the diffraction pattern. The rietveld refinement of the XRD pattern between 25 and $48^{\circ} 2 \theta$ permit to quantify the phyllosilicate content and to precise their structure (Fig. 4). The best fitting refinement is obtained using a mixture of Muscovite $1 M$, Muscovite $2 M_{1}$ and ferroan clinochlore II $b$ (Fig. 4). Table 1 presents the results of the refinement on seven samples (four from the HDZ, three from the HR). It can be noticed that chlorite (clinochlore) is in similar proportion in all samples. The Muscovite $2 M_{1}$ polytype is the dominant mica phase but a small proportion of muscovite $1 M$ is present in all samples from the HR and one sample from the HDZ. The $b$ cell

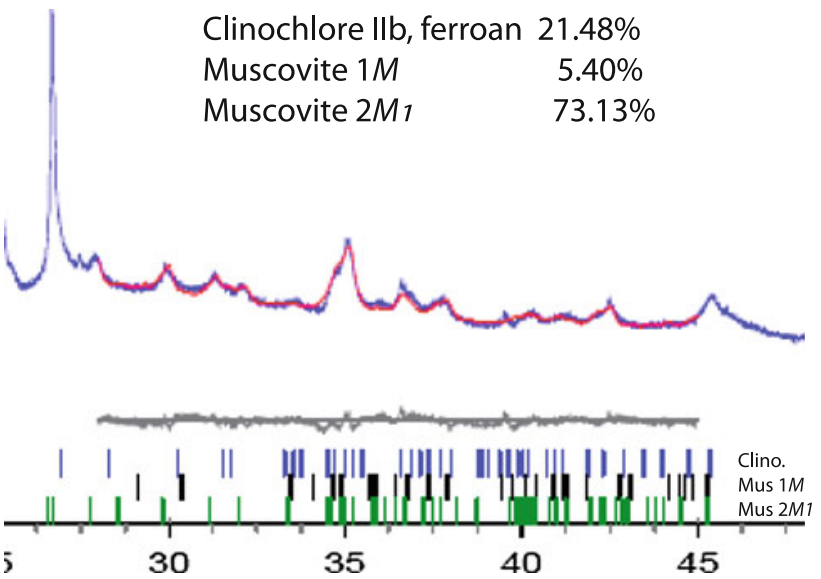

Fig. 4 XRD pattern of the $<2 \mu \mathrm{m}$ fraction of sample TO31 and result of Rietveld refinement of the spectra between 28 and $45^{\circ} 2 \theta$. The calculated spectra is given in red, the difference between both spectra is in black, and the position of all peaks for the refined minerals are shown in blue (clinochlore IIb ferroan), in black (muscovite $1 M$ ) and in green (muscovite $2 M_{1}$ ). The conventional Rietveld agreement factor, Rwp is 2.02

Table 1 Rietfeld-refined X-ray diffraction data

\begin{tabular}{lllll}
\hline & $\begin{array}{l}\text { Clinochlore } \\
(\%)\end{array}$ & $\begin{array}{l}\text { Muscovite } \\
1 \mathrm{M}(\%)\end{array}$ & $\begin{array}{l}\text { Muscovite } \\
2 \mathrm{M}_{1}(\%)\end{array}$ & $\begin{array}{l}\mathrm{b} \\
\text { parameter }\end{array}$ \\
\hline T0062ND HDZ & 16.5 & 0 & 83.5 & 9.004 \\
T0122ND HDZ & 27.5 & 0 & 72.5 & 8.998 \\
T0192ND HDZ & 21.9 & 0.2 & 77.9 & 9.011 \\
T0272ND HDZ & 22.1 & 2.1 & 75.8 & 9.001 \\
T0312ND HR & 22.5 & 5.2 & 72.3 & 9.001 \\
T0342ND HR & 17.6 & 4.2 & 78.2 & 9.003 \\
T0352ND HR & 23.5 & 2.9 & 73.6 & 9.001 \\
\hline
\end{tabular}

$H R$ host rock, $H D Z$ highly deformed zone

parameter calculated for each sample is between 8.998 and 9.011 with an average of $9.002 \AA$.

\subsection{Microstructural investigations}

\subsubsection{SEM data}

Figure 5a displays a typical view of the microstructures observed at the optical scale on the Monte Perdido thrust fault. Following the typology defined by Lacroix et al. (2011), the calcite-quartz shear veins $\left(\mathrm{S}_{\mathrm{V}} 1\right)$ are folded and cross-cut by calcite-quartz boudinage veins $\left(\mathrm{E}_{\mathrm{V}} 2\right)$. The highly deformed sediments display a typical $\mathrm{S}-\mathrm{C}$ structure and host the very thin $\mathrm{S}_{\mathrm{V}} 2$ chlorite shear veins (Fig. $5 b$ ). The obliquity between shear surfaces and cleavage in the $\mathrm{S}-\mathrm{C}$ structure indicates a top to the south sense of shear (Fig. 5b).

Figure $5 \mathrm{c}$ shows that the $\mathrm{S}_{\mathrm{V}} 2$ veins are well defined under the SEM backscattered images by their high electron contrast compared to the matrix. They correspond to very 

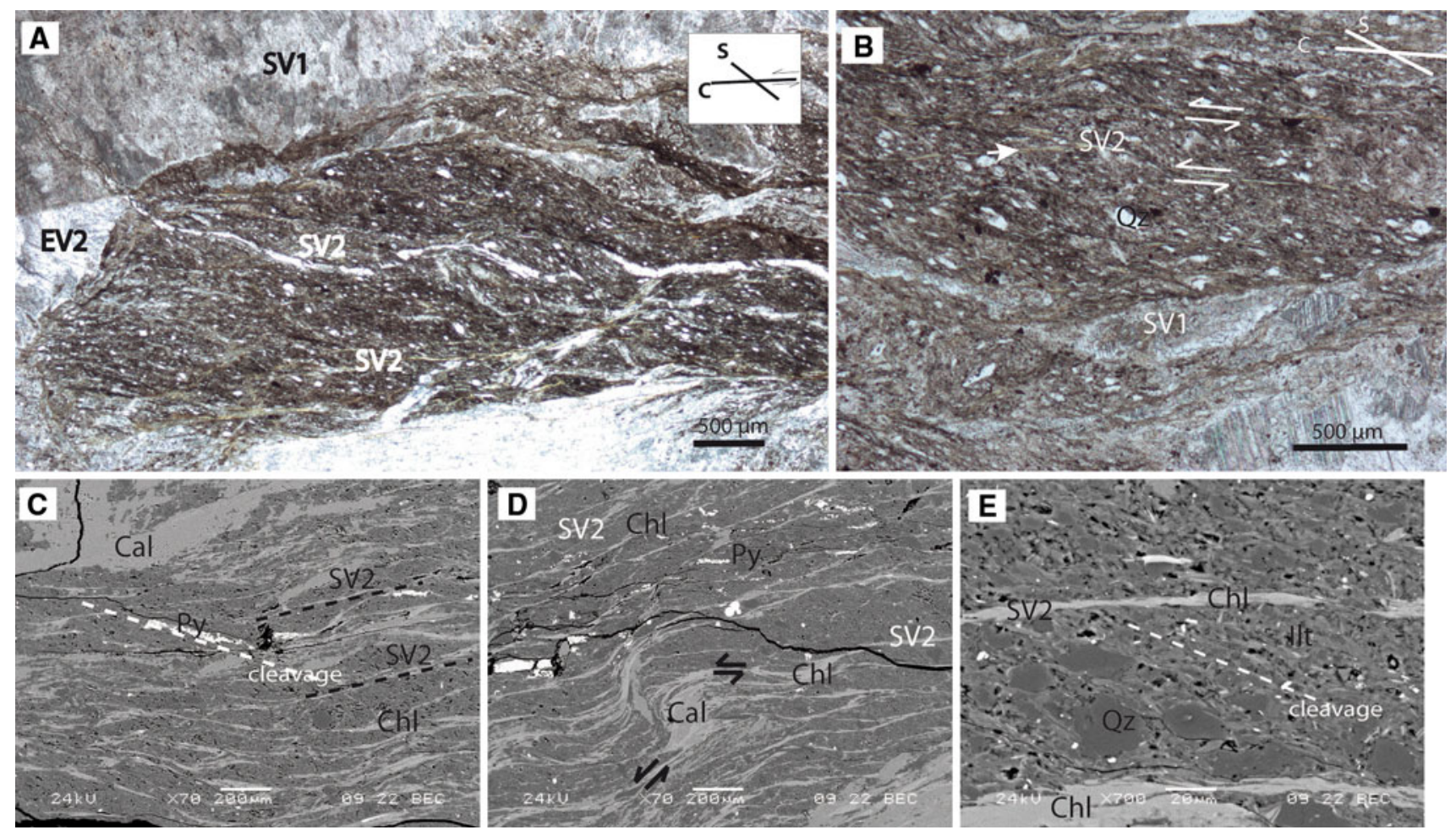

Fig. 5 Optical microscope images (a, b) and scanning backscattered electron images at different magnifications $(\mathbf{c}-\mathbf{e})$ of the highly deformed clay-rich sediment from the fault core zone $S_{V} l$ shear vein 1 (first stage of deformation), $S_{V} 2$ shear vein 2 (second stage of deformation), $E_{V} 2$ Extension vein 2, Cal calcite, $P y$ pyrite, $C h l$ chlorite, Ilt Illite, $Q z$ quartz. On the SEM images the cleavage is underlined by white dashed lines, the shear veins by black dashed lines on image $\mathbf{c}$. The arrows indicate the sense of shear thin (about $10 \mu \mathrm{m}$ ) seams filled with chlorite always following the $\mathrm{C}$ and $\mathrm{C}^{\prime}$ shear surfaces. Figure $5 \mathrm{~d}$ reveals that calcite can be associated to chlorite along extension relay zone corresponding to incremental pull-apart openings following a crack-seal mechanism (Lacroix et al. 2011). Small pyrite crystals are also distinguished by their high contrast and they appear as elongated aggregates along the cleavage (Fig. 5c-e).

SEM images of a chlorite-calcite shear vein in an ionmilled sample are shown in Fig. 6. The vein comprises numerous parallel chlorite veinlets sometimes associated to calcite. At high magnification (Fig. 6b, c), the angular relationship between the chlorite veinlets and cleavage defines $\mathrm{S}-\mathrm{C}$ structure indicating the sense of shear. Chlorite crystals are preferentially elongated along the shear veins whereas other clay minerals and quartz follow the cleavage.

\subsubsection{TEM data}

5.2.2.1 Illite The TEM observations performed on cleavage structures reveal that cleavage is underlined by preferentially oriented illite (Fig. 7). The illites are elongated crystals $20-30 \mathrm{~nm}$ thick (Fig. 7). When oriented perpendicular to 001 direction, they display the $10 \AA$ regular periodicity corresponding to their TOT layers with the typical mottle texture as described by Merriman et al. (1995) related to their sensitivity to the electron beam. Most illite particles are preferentially oriented along the cleavage but locally, in quartz pressure shadows, illite crystals with different orientation are present (Fig. 8). The illite layers are not deformed by the quartz grain and they display well defined grain boundaries suggesting that they are authigenic and that they precipitated in the open space created by the increase of normal stress at the quartz mica interface during burial.

Lattice fringe images of the mica particles at various focusing conditions shows the regular $10 \AA$ periodicity corresponding to the (001) stacking sequence. However, locally, in favourable orientation conditions, a two layer periodicity (20 $)$ ) is superposed (Fig. 9a, c). The selected area electron diffraction (SAED) pattern of the same crystal displays along the (hkl) row the substructure spots reflecting a two layer periodicity. These data suggest that micas are $2 M_{1}$ polytypes. Images targeted on the edges of mica particles display their spindle-like terminations (Fig. 9b), with step-like layer terminations composed of two layers. These well-defined layer boundaries suggest that this crystal is newly formed.

5.2.2.2 Chlorite Chlorite occurs preferentially in large packets of 100-200 nm thick crystals. Low magnification images show that some of the crystals display lattice 

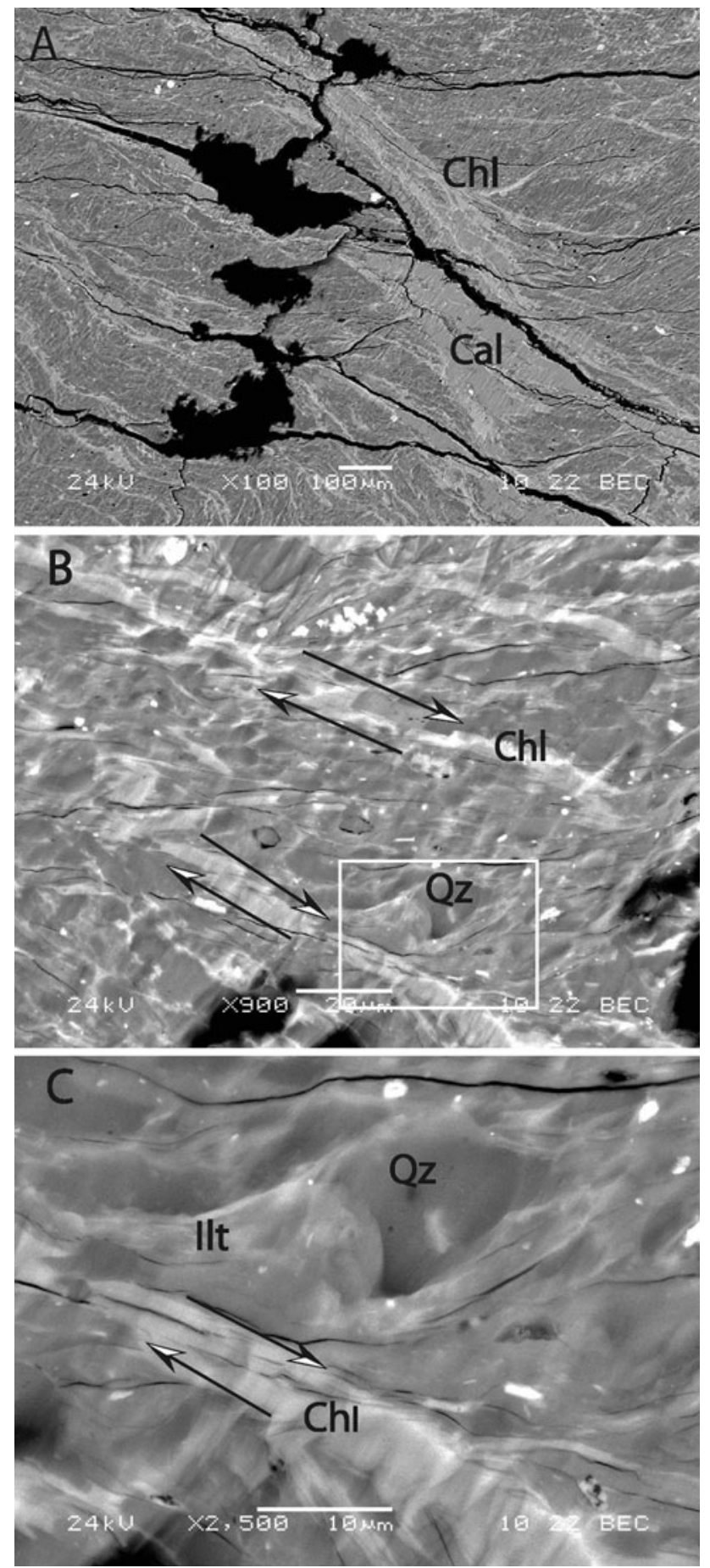

Fig. 6 Backscattered scanning electron images on ion-milled sample from the highly deformed clay-rich sediment from fault zone. a General view of the sample. The black area corresponds to the hole created by the ion-milling. Chlorite and calcite shear veins are clearly distinguished from the grey matrix. b, c Views at higher magnification of the shear vein and cleavage relationship. The arrows indicate the sense of shear

distorsion suggesting intracrystalline deformation (Fig. 10). On Fig. 10b, chlorite crystals orientation defines an "ear of wheat" texture that could be explained by an active

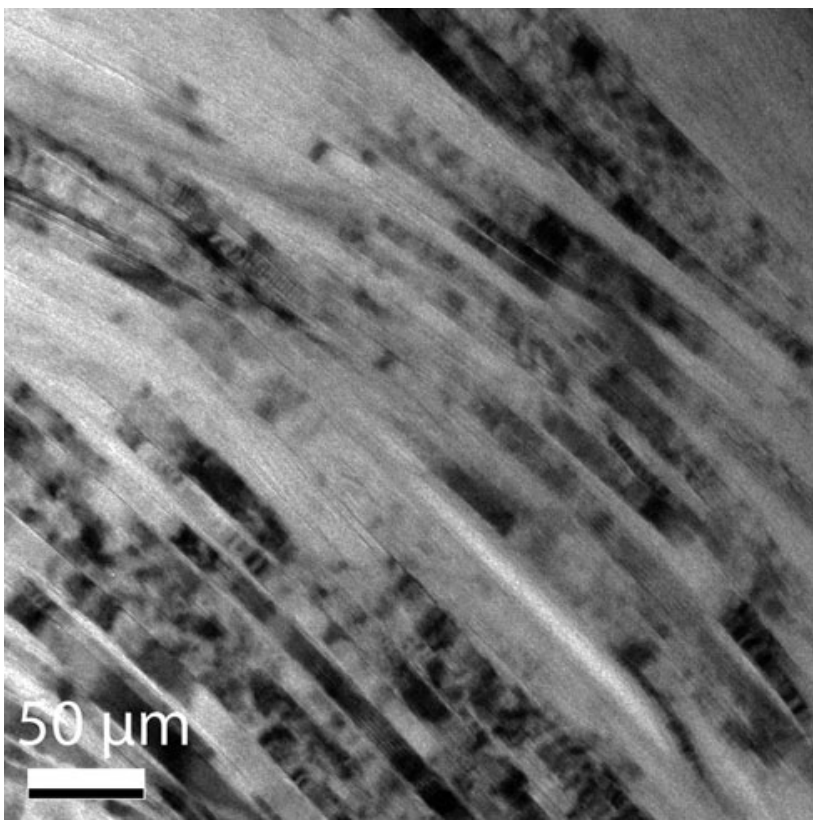

Fig. 7 Low magnification transmission electron microscope (TEM) image of the cleavage with illite crystals showing preferential crystallographic orientation

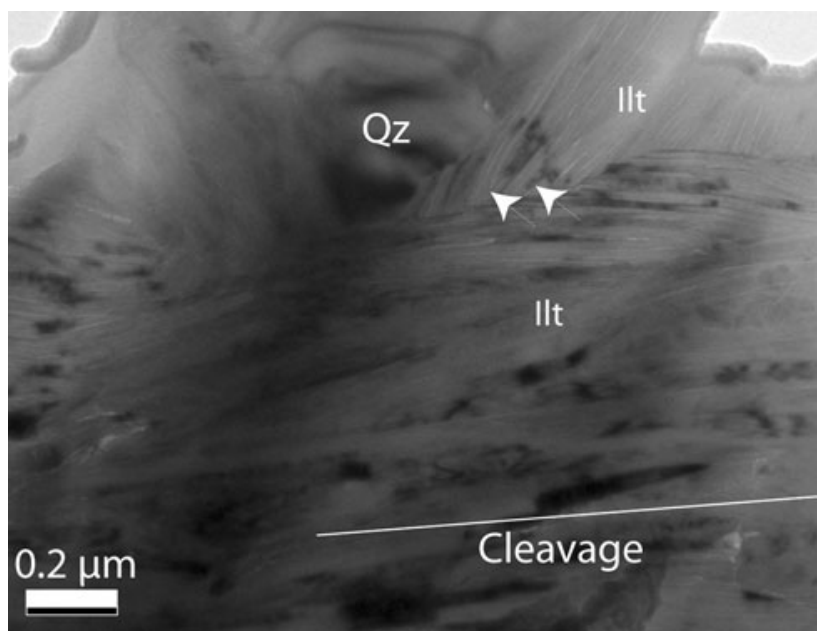

Fig. 8 TEM image showing newly formed illite in the pressure shadow of a quartz grain. The arrows show the well-defined grain boundaries between illite crystals of different orientations Ilt illite, $Q z$ quartz

shearing motion during and after chlorite crystallization. On Fig. 11, a large crystal of chlorite displays the $14 \AA$ (001) stacking sequence and numerous stacking faults.

In large domains where chlorite is the only phase (corresponding to the shear veins), TEM image of Fig. 12 shows newly formed chlorite crystals having well defined grain boundaries and deformed crystals suggesting a textural rearrangement related to synchronous growth and deformation processes. 

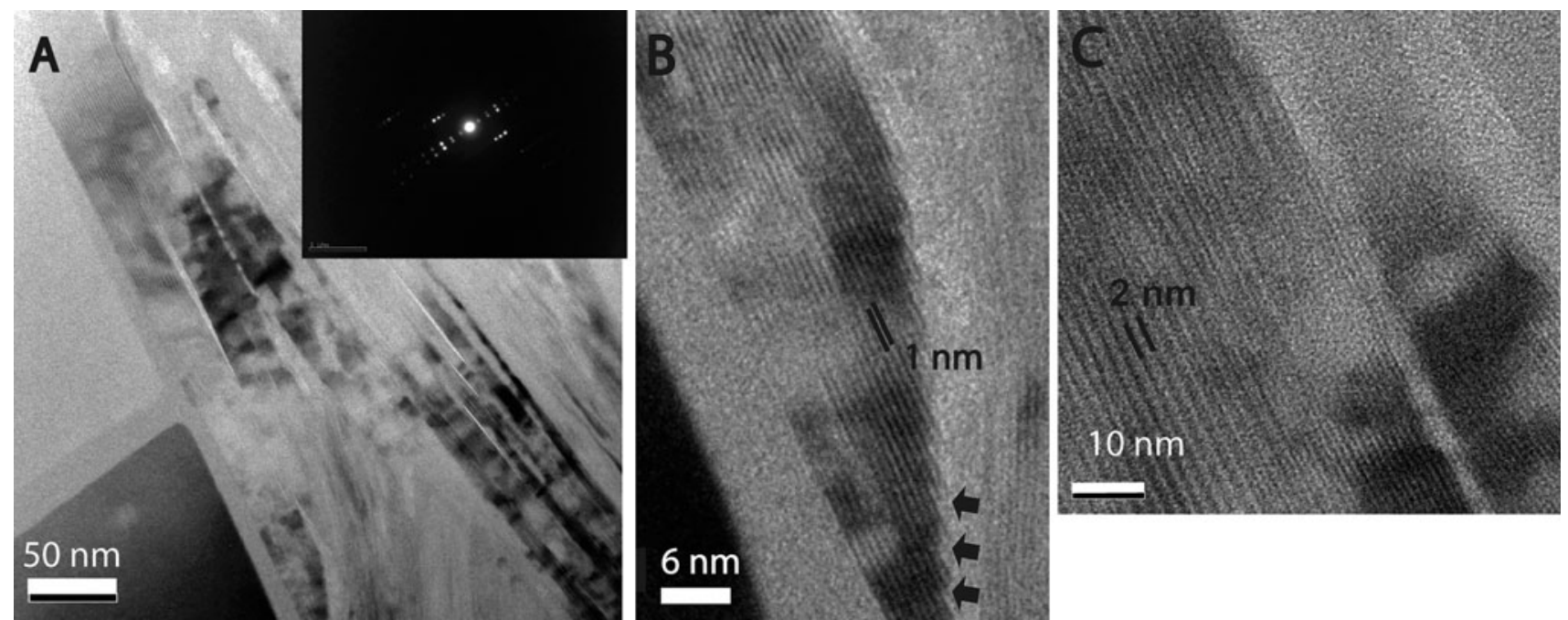

Fig. 9 TEM image and various magnification of newly formed $2 M$ illite. a TEM image of illite with 2 and $1 \mathrm{~nm}$ stacking sequence. The $2 M$ polytype is confirmed by the selected area diffraction pattern. $\mathbf{b}$ Layer

termination of a illite crystal. The step of two layers are shown by the arrows. The stacking sequence is $1 \mathrm{~nm}$. c HRTEM image of the illite stacking sequence. The $2 \mathrm{~nm}$ periodicity is related to the $2 M$ polytype
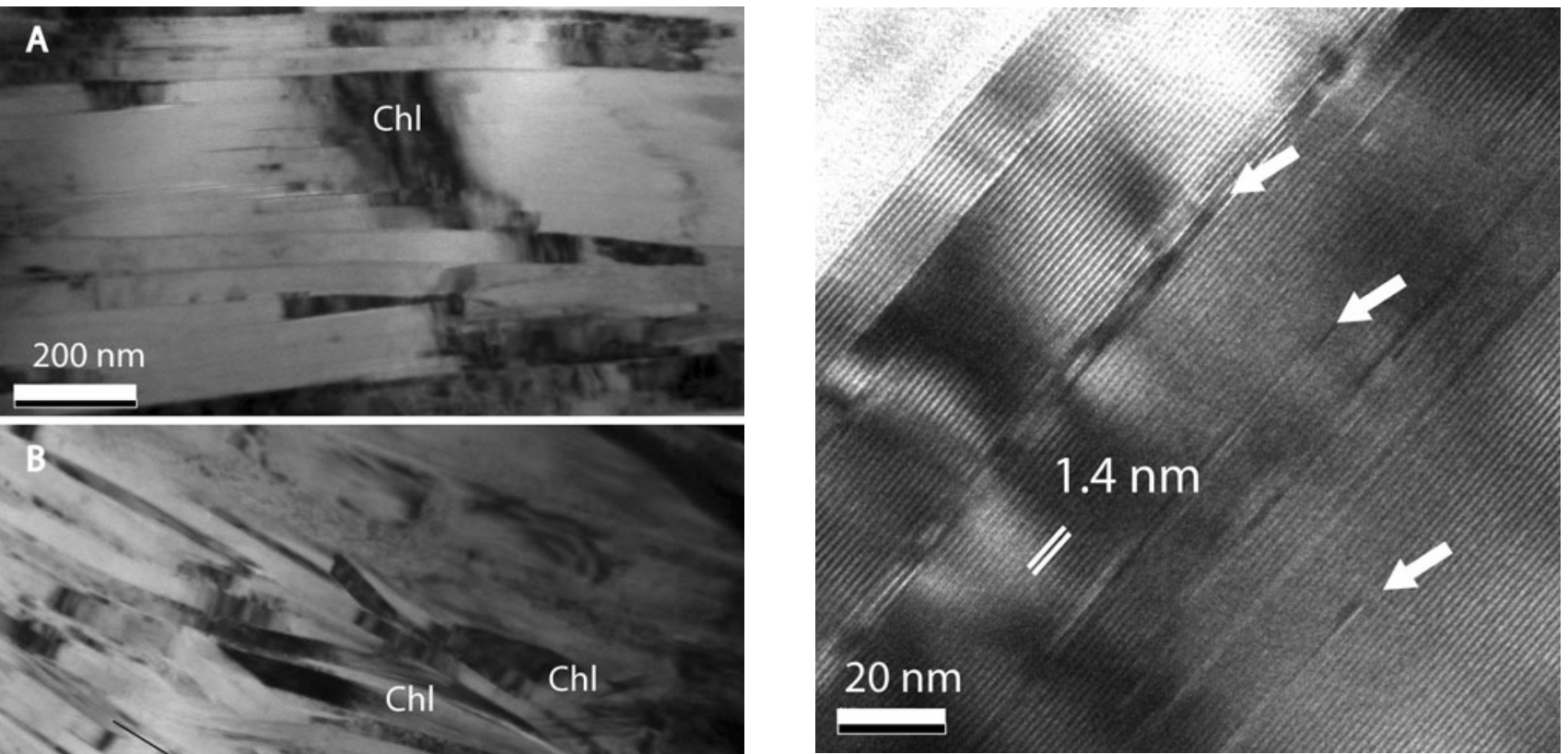

Fig. 11 High resolution transmission electron microscope (HRTEM) image of a chlorite crystal. The stacking has a periodicity of $1.4 \mathrm{~nm}$. The arrows show the stacking faults

staking disorder as reflected by streaking parallel to $\mathrm{c}^{*}$ for $\mathrm{k} \neq 3 \mathrm{n}$ reflexions (Fig. 14).

Fig. 10 TEM image of chlorite crystals filling the shear veins. The contrast variation along the crystal suggest intracrystalline deformation $(\mathbf{a}, \mathbf{b})$. Cleavage orientation is indicated on $\mathbf{b}$

Intergrowth of chlorite and illite are common. The interfaces between these two phases are generally incoherent (Fig. 13). SAED pattern on chlorite crystal indicates

\section{Discussion}

6.1 Origin and behaviour of phyllosilicates during deformation

Lacroix et al. (2012) demonstrate that the clay fraction of the studied host sediment is dominated by illite in 


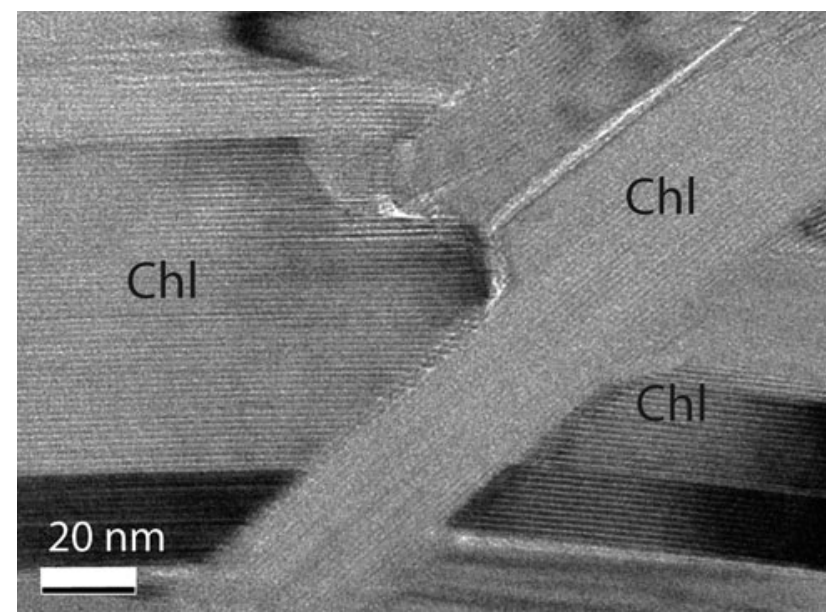

Fig. 12 TEM image of newly chlorite crystals in $\mathrm{SV}_{2}$ veins. The textural arrangement of chlorite crystals suggest synchronous growth and deformation processes

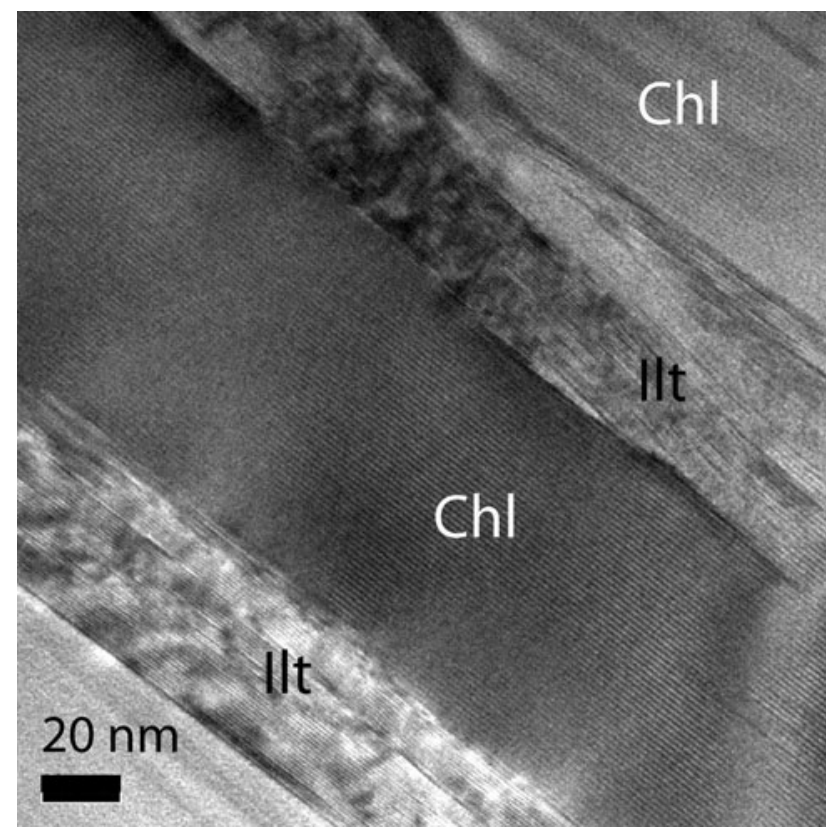

Fig. 13 TEM image of chlorite illite interfaces. Illite displays a mottled contrast whereas chlorite occurs as large crystals

limestones (Alveolina limestone from the hanging wall), whereas the pelites and sandstones (Hecho Group turbidites from the footwall) contain chlorite and illite in similar proportions. They also found detrital chlorite-illite aggregates of various sizes in pelites, sometimes accumulated along pressure-solution surfaces as an "insoluble residue". These assemblages were also described by Bauluz-Lázaro et al. (2008), in the Hecho Group turbidites further south in the Jaca basin. In the highly deformed core zone of the Monte Perdido thrust fault, a pervasive cleavage with preferential orientation of phyllosilicates is well characterized at the optical scale (Lacroix et al. 2011). The XRD analyses of the

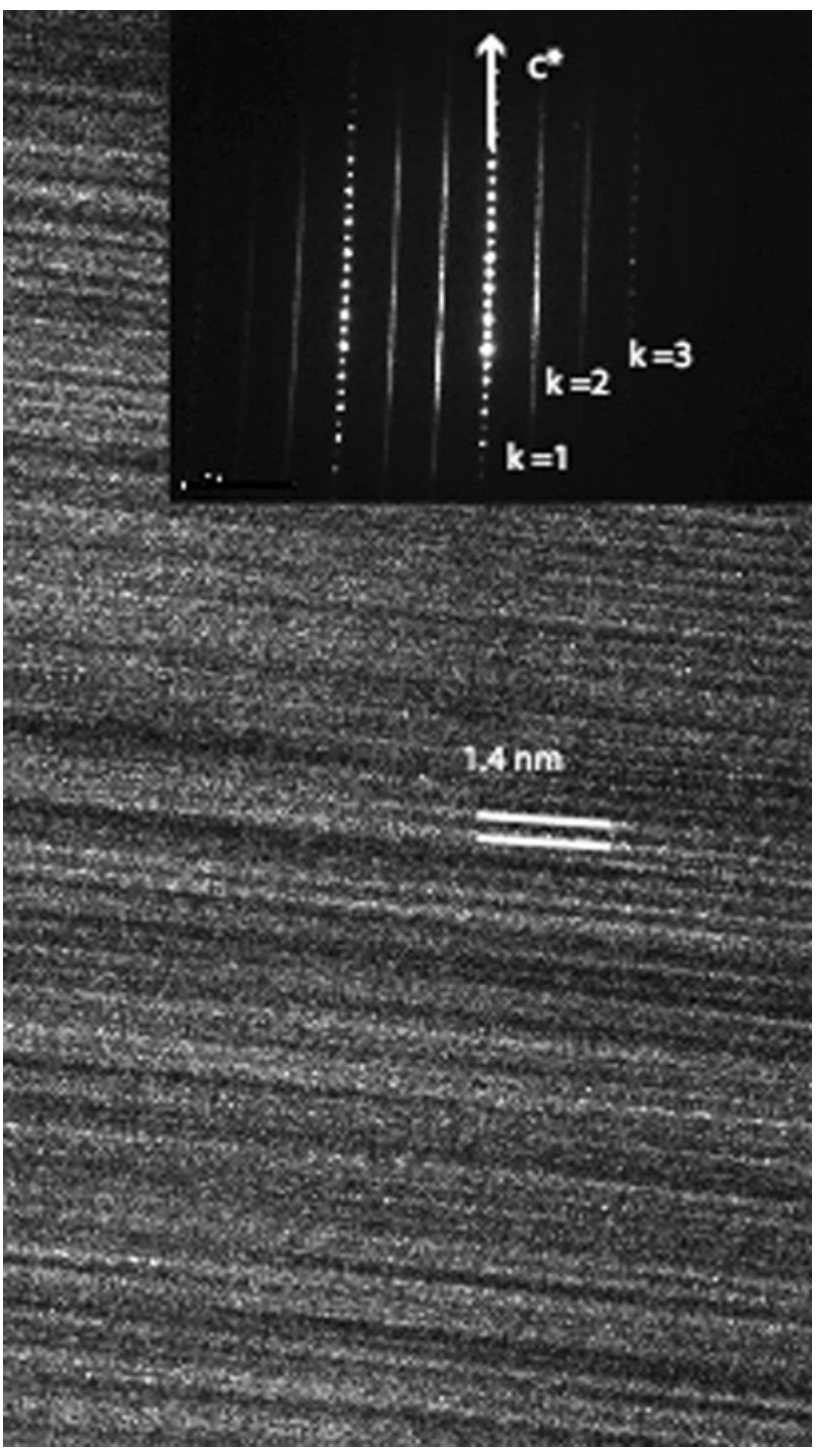

Fig. 14 HRTEM image and selected area electron diffraction (SAED) pattern of a chlorite crystal suggesting staking disorder

powdered clay fraction performed in the present study show that the clay assemblage is the same in the host rock and in the highly deformed zone. The Rietveld refinement demonstrates that illite is dominated by the $2 M_{1}$ polytype component in all samples and that a small proportion of $1 M$ illite exists in the host rock. Chlorite is also present as clinochlore $I I b$. The poor diversity of phyllosilicate in the Monte Perdido thrust fault is consistent with the data of Merriman (2002) and Kameda et al. (2011b) who found illite-chlorite assemblages in low grade metamorphic rocks from convergent basin contexts. According to Merriman (2002), the absence of mineralogical diversity could be related to the restricted fluid circulation in these tectonic environments. This author suggests that fabric formation has an important role in clay mineral formation in this context. 
The clay mineralogical assemblage and the nature of chlorite and illite polytypes described here are consistent with the P-T conditions established by Lacroix et al. $(2011,2012)$ who suggest a temperatures of about 200 and $240{ }^{\circ} \mathrm{C}$ and a maximum depth of $6 \mathrm{~km}$ during Monte Perdido thrust fault emplacement et reactivation.

The TEM observations of the fault core samples display the preferential orientation of phyllosilicate. The mineralogical assemblage is partially inherited from the host rock but displays a stronger fabric with well-expressed CS structures. Aseismic sliding of active fault by pressure solution creep has been well documented in the San Andreas Fault observatory at depth by Gratier et al. (2011) who demonstrate that such mechanism can accommodate $20 \mathrm{~mm} /$ year sliding.

In the studied samples, we observe mineral segregation in the highly deformed zone. Newly formed $2 M_{1}$ illite is present along the cleavage whereas $I I b$ chlorite (clinochlore) crystals fill $\mathrm{S}_{\mathrm{V}} 2$ shear veins suggesting mineral precipitation and recrystallization in the presence of fluids in low-grade metamorphic conditions.

The textural arrangement of clays observed by TEM in the studied fault demonstrates that the clay mineral enrichment in the highly deformed zone is not only due to the calcite and quartz departure by pressure solution mechanisms but also to neoformation of clay minerals by dissolution-recrystallization processes. XRD analyses of bulk rock suggest that both illite and chlorite content increase relative to quartz during deformation.

The different lithologies of the hanging and footwall and the heterogeneity of the turbidites do not allow to establish mass balance calculation and quantification of chemical transfer by fluids. Kameda et al. (2011a), studying the mineralogical changes implying clays in an ancient accretionary complex in the Shimanto Belt (Japan), observed the formation of a slaty cleavage consisting of a dense network of chlorite and mica assemblage linked to increasing deformation. Based on the comparison of samples from different metamorphic grade, these authors propose a reaction mechanism implying illite as a precursors and its progressive transformation into the phengite + chlorite assemblage. This reaction requires the presence of $\mathrm{Fe}$ and $\mathrm{Mg}$ that would be released by the alteration of accessory minerals (e.g. biotite, pyrite). Indeed, these authors suggest the absence of chemical input from outside. In the fault zone studied here, stable isotope analyses on synkinematic calcite veins and their comparison to the calcite matrix from the fault zone and host sediments, suggest that calcite precipitated from a fluid in isotopic equilibrium with sediments (Lacroix et al. 2011). Consequently, the mineralogical reactions observed in this study, could appear in a relatively closed system. The observation of partially altered pyrites aggregates with elongated shape along cleavages suggests that interaction between fluid and sediments during deformation allowed pyrite oxidation and partial dissolution providing $\mathrm{Fe}$ for chlorite formation.

\subsection{Pressure-temperature conditions}

Coupling compositional chlorite geothermometry (Vidal et al. 2001, 2005; Inoue et al. 2009) with stable isotope thermometry on quartz and chlorite, Lacroix et al. (submitted) found similar temperature range with a mean value of $240{ }^{\circ} \mathrm{C}$ for the second deformation stage (chlorite shear vein formation). According to fluid inclusion study on contemporaneous quartz veins, a burial of $6.5 \mathrm{~km}$ is necessary to obtain this temperature of $240{ }^{\circ} \mathrm{C}$. These temperature-burial conditions are consistent with a geothermal gradient of $34{ }^{\circ} \mathrm{C} / \mathrm{km}$ and correspond to the late diagenetic-anchizone boundary (Frey and Robinson 1999). Diagenetic and metamorphic conditions can be recorded by the $b$ dimension of mica (Abad et al. 2003). In the present study, the XRD analyses on disoriented clay fraction revealed an average $b$ dimension of 9.002. Guidotti and Sassi (1976) estimated that $b$ cell values between 9 and 9.04 correspond to the intermediate pressure facies for a geothermal gradient of $25-35^{\circ} \mathrm{C} / \mathrm{km}$. The burial depth of $6.5 \mathrm{~km}$ deduced from previous fluid inclusion study by Lacroix et al. (2011) is therefore consistent with the pressure recorded by micas.

Newly formed chlorite presents a disordered staking sequence (see above). Similar structures were found by Lopez-Minguira and Nieto (2000) in clastic sediment from Hesperian Massif (Spain) in burial diagenetic conditions. Furthermore, Schmidt and Livi (1999) investigated stacking disorder and crystal growth in chlorite from subgreenshist facies outcroping in the Helvetic nappes, where they found that chlorite displays an increase in stacking ordering with increasing metamorphic grade in sandstones. The disordered staking sequence of chlorite observed in the Monte perdido thrust fault is then consistent with the low metamorphic conditions reached by the studied rocks (Lacroix et al. 2011).

\subsection{Role of phyllosilicates on fault reactivation}

As suggested by the SEM and TEM observations, the (001) chlorite planes are parallel to shear surfaces whereas illite underlines cleavages. Both minerals display textural evidences of synkinematic growth and/or recrystallization. The activity of the Monte Perdido fault is clearly associated to deformation processes dominated by pressure solution mechanisms and clay mineral recrystallization. Pressuresolution associated to deformation permits the departure of calcite and quartz from the rock matrix and its precipitation in extension and shear veins (Lacroix et al. 2011). 
The element mobility is very small at the fault scale but it creates a mineralogical segregation with domains enriched in clay minerals. Many experiments demonstrated that the amount of clay minerals in fault rocks can influence the friction fault strength (i.e. Tembe et al. 2006; Numelin et al. 2007; Morrow et al. 2007). The relationship between frictional strength and the amount of clay minerals in natural fault gouge has been investigated by Numelin et al. (2007). They measured the friction coefficient at normal stress from 5 to $150 \mathrm{MPa}$, and they found a coefficient of $0.2-0.4$ for samples containing more than $50 \%$ total clay content, whereas for most samples with lower clay content the friction coefficient was about 0.6-0.7, consistent with Byerlee's law (Byerlee 1978). Ikari et al. (2011) found a systematic relationship between absolute frictional strength and the unstability of fault slip from experimental measurement on a wide range of mineralogical constituents. Gouges with friction coefficient of 0.25 are those enriched in clay minerals (illite shales, chlorite schist) and display stable sliding behaviour whereas gouges with quartz and feldspar display unstable sliding behaviour.

The weakness of clay gouges has been attributed to the strength of bonds between sheet silicate surfaces (Morrow et al. 2000). However, the mechanical properties of phyllosilicates are well known to be anisotropic. When shortened perpendicular to the basal plane, phyllosilicates have compressive strength comparable to that of quartz and feldspar (and even stronger). When shortened at $45^{\circ}-0^{\circ}$ to (001), strength is one order of magnitude lower (Wintsch et al. 1995). Consequently, the development of foliation underlined by phyllosilicates (clays) may favours sliding behaviour. Slip could occur along grain boundaries or by dislocation glide along (001) (Wintsch et al. 1995). Moore and Lockner (2004) showed that the low value of $\mu$ can correlate with (001) interlayer bond strengths of phyllosilicates. They also displayed that a decrease of $\mu$ can be observed when changing from dry to water saturated conditions. This change is particularly important for chlorite.

In the studied Monte Perdido fault zone outcrop, there is textural evidence that the late stage of deformation strongly affected the clay-rich area with the reactivation of shear veins and precipitation of chlorite. TEM observations clearly demonstrate that chlorite growths syntectonically in shear veins confirming their major role during deformation. The specific crystallographic orientation of chlorite could represent preferential sliding horizon controlled by its low frictional properties. Brown et al. (2003) suggest that the internal chlorite friction coefficient along (001) plane is 0.26 . Therefore the presence of chlorite along shear veins and their preferential orientation with (001) parallel to shear acts as a weakening process and would favours Monte Perdido fault creeping.

\section{Conclusions}

The studied Monte Perdido thrust fault from the southern Pyrenees showed the following:

- This enrichment is related to pressure solution mechanisms during deformation along the fault. The dissolution of calcite and quartz in the sediment and their precipitation in veins induces a passive increase of clay minerals in the fault core zone matrix.

- The SEM and TEM investigations of the highly deformed fault zone demonstrate that during a late deformation stage a iron-rich chlorite precipitated in shear veins $\left(\mathrm{S}_{\mathrm{V}} 2\right)$ whereas recrystallization of $2 M_{1}$ illite occurred along cleavage planes.

- The occurrence of $2 M_{1}$ illite (muscovite) and $I I b$ chlorite (clinochlore) is consistent with the $\mathrm{P}-\mathrm{T}$ conditions calculated from fluid inclusion study and stable isotope analyses $\left(240{ }^{\circ} \mathrm{C}\right.$ and $\left.6.5 \mathrm{~km}\right)$.

- The abundance of phyllosilicates allowed thrust fault creeping. Slip weakening is favoured by the syntectonic growth of chlorite along shear veins and their low friction coefficient.

Acknowledgments We thank B. Bauluz and A. M. Boullier for their constructive reviews. This work was realized within the framework of the $3 \mathrm{~F}$ "Fault, Fluid, Flow" program funded by INSUCNRS. We thank Nicolas Rouge from the University of FrancheComté (Besancon) for SEM technical support and Rémi Chassagnon (University of Bourgogne, Dijon) for his help on the TEM preparation and technical assistance on TEM.

\section{References}

Abad, I., Gutierrez-Alonso, G., Nieto, F., Gertner, I., Becker, A., \& Cabero, A. (2003). The structure and the phyllosilicates (chemistry, crystallinity and texture) of Talas Ala-Tau (Tien Shan, Kyrgyz Republic): comparison with more recent subduction complexes. Tectonophysics, 365(1-4), 103-127.

Bauluz-Lázaro, B., González-López J.-M., Yuste-Oliete, A., \& Mayayo-Burillo, M.-J. (2008). Evolución Diagenética de las Turbiditas del Grupo Hecho (Eoceno) en la Cuenca de Jaca (España), SEM 2008, Zaragoza.

Beaumont, C., Muñoz, J. A., Hamilton, J., \& Fullsack, P. (2000). Factors controlling the Alpine evolution of the central Pyrenees inferred from a comparison of observations and geodynamical models. Journal of Geophysical Research-Solid Earth, 105, 8121-8145.

Brown, K. M., Kopf, A., Underwood, M. B., \& Weinberger, J. L. (2003). Compositional and fluid pressure controls on the state of stress on the Nankai subduction thrust: a weak plate boundary. Earth and Planetary Science Letters, 214, 589-603.

Buatier, M. D., Chauvet, A., Kanitpanyacharoen, W., Wenk, R., Ritz, J. F., \& Jolivet, M. (2012). Origin and behavior of clay minerals in the Bogd fault gouge. Mongolia Journal of Structural Geoogy, $34,77-90$.

Byerlee, J. D. (1978). Friction of rocks. Pure and Applied Geophysics, 116, 615-626. doi:10.1007/BF00876528. 
Choukroune, P., Roure, F., Pinet, B., \& Ecors Pyrenees, T. (1990). Main results of the ECORS Pyrenees profile. Tectonophysics, 173(1-4), 411.

Collettini, C., Viti, C., Smith, S. A. F., \& Holdsworth, R. E. (2009). Development of interconnected talc networks and weakening of continental low-angle normal faults. Geol, 37, 567-570.

der Pluijm, Van. (2011). Natural fault lubricants. Nature Geosciences, 4, 217-2018

Frey, M. \& Robinson, D. (1999). Low grade metamorphism. Blackwell Sciences edition, 303 pp.

Gratier, J.-P., Richard, J., Renard, S., Mittempergher, S., Doan, M. L., Di Toro, G., et al. (2011). Aseismic sliding of active faults by pressure solution creep: evidence from the San Andreas Fault observatory at depth. Geology, 39, 1131-1134.

Guidotti, C. V., \& Sassi, F. P. (1976). Muscovite as a petrogenetic indicator mineral in pelitic schists. Neues Jahrbuch für Mineralogie Abhandlungen, 127, 97-142.

Holdsworth, R. E., van Diggelen, E. W. E., Spiers, C. J., de Bresser, J. H. P., Walker, R. J., \& Bowen, L. (2011). Fault rocks from the SAFOD core samples: implications for weakening at shallow depth along the San Andreas Fault, California. Journal of Structural Geology, 33, 132-144.

Ikari, M., Marone, C., \& Saffer, D. M. (2011). On the relation between fault strength and frictional stability. Geology, 39, $83-86$.

Inoue, A., Meunier, A., Patrier-Mas, P., Rigault, C., Beaufort, D., \& Vieillard, P. (2009). Application of chemical geothermometry to low-temperature trioctahedral chlorites. Clays and Clay Minerals, 57, 371-382.

Kameda, J., Raimbourg, H., Kogure, T., \& Kimura, G. (2011a). Lowgrade metamorphism around the down-dip limit of seismogenic subduction zones: example from an ancient accretionary complex in the Shimanto Belt, Japan. Tectonophysics, 502, 383-392.

Kameda, J., Ujiie, K., Yamaguchi, A., \& Kimura, G. (2011b). Smectite to chlorite conversion by frictional heating along subduction thrust. Earth Planetary Science Letters, 305, 161170

Labaume, P., Seguret, M., \& Seyve, C. (1985). Evolution of a turbiditic foreland basin and analogy with an accretionary prism: example of the Eocene south-Pyrenean Basin. Tectonics, 4, 661-685.

Lacroix, B., Buatier, M., Labaume, P., Travé, A., Dubois, M., Charpentier, D., et al. (2011). Microtectonic and geochemical characterization of thrusting in a foreland basin: the example of South-Pyrenean orogenic prism (Spain). Journal of Structural Geology, 33, 1359-1377.

Lacroix, B., Charpentier, D., Buatier, M., Vennemann, T., Labaume, P., Adatte, T., et al. (2012). Clay minerals in thrust faults: use as a proxy for P-T conditions (example of Monte Perdido thrust fault, southern Pyrenees). Contribution to Mineralogy and Petroology, 162,. doi:10.1007/s00410-011-0718-0.

Lopez-Minguira, A., \& Nieto, F. (2000). Transmission electron microscopy study of very low-grade metamorphic rocks in Cambrian sandstones and shales, Ossa-Morena zone, southern Spain. Clays and Clay Minerals, 48, 213-223.

Merriman, R. J. (2002). Contrasting clay mineral assemblages in British Lower Paleozoic slate belts: the influence of geotectonic setting. Clay Minerals, 37, 207-219.

Merriman, R. J., Roberts, B., Peacor, D. R., \& Hirons, S. R. (1995). Strain-related differences in the crystal-growth of white mica and chlorite: a TEM and XRD study of the development of metapelitic microfabrics in the southern upland thrust terrane, Scotland. Journal of Metamorphic Geology, 13, 559-576.

Moore, D. E., \& Lockner, D. A. (2004). Crystallographic controls on the frictional behaviour of dry and water-saturated sheet structure minerals. Journal of Geophysical Research, 109, 1-16.
Morrow, C. A., Moore, D. E., \& Lockner, D. A. (2000). The effect of mineral bond strength and adsorbed water on fault gouge frictional strength. Geophysical Research Letters, 27, 815-818.

Morrow, C., Solum, J. G., Tembe, S., Lockner, D., \& Wong, T. (2007). Using drill cutting separates to estimate the strength of narrow shear zones at SAFOD. Geophysical Research Letters, 34, L11301.

Muñoz, J. A. (1992). Evolution of a continental collision belt: ECORS- Pyrenees crustal balanced cross-section. In MCClay, K. (ed.) Thrust tectonics, Berlin: Springer, pp. 235-246.

Numelin, T., Marone, C., \& Kirby, E., (2007). Frictional properties of natural fault gouge from a low-angle normal fault, Panamint Valley, California. Tectonics, 26, TC2004.

Oliva-Urcia, B., Larrasoaña, J. C., Pueyo, E. L., Gil, A., Mata, P., Parés, J. M., et al. (2009). Disentangling magnetic subfabrics and their link to deformation processes in cleaved sedimentary rocks from the Internal Sierras (west central Pyrenees, Spain). Journal of Structural Geology, 31, 163-176.

Rutter, E. H., Maddock, R. H., Hall, S. H., \& White, S. H. (1986). Comparative microstructures of natural and experimentally produced clay-bearing fault gouges. Pure and Applied Geophysics, 124, 3-30.

Schmidt, D., \& Livi, K. J. T. (1999). HRTEM and SAED investigations of polytypism, staking disorder, crystal growth, and vacancies in chlorite from subgreenschist facies outcrop. American Mineralogist, 84, 160-170.

Séguret, M. (1972). Etude tectonique des nappes et séries décollées de la partie centrale du versant sud des Pyrénées. Publications de l'Université des Sciences et Technologiques du Languedoc (Ustela), $155 \mathrm{pp}$.

Sibson, R. H. (1973). Interactions between temperature and pore-fluid pressure during earthquake and a mechanism for partial or total stress relief. Nature (Physical Science), 243(126), 66-68.

Smith, S. A. F., \& Faulkner, D. R. (2010). Laboratory measurements of the frictional properties of the Zuccale low angle normal fault, Elba Island, Italy. Journal of Geophysical Research, Solid Earth, 115, B202407.

Takahashi, M., Mizoguchi, K., Kitamura, K., \& Masuda, K. (2007). Effects of clay content on the frictional strength and fluid transport property of faults. Journal of Geophysical ResearchSolid Earth, 112, B08206. doi:10.1029/2006JB004678.

Teixell, A. (1996). The Anso transect of the southern Pyrenees: basement and cover thrust geometries. Journal of the Geological Society, 153, 301-310.

Teixell, A. (1998). Crustal structure and orogenic material budget in the west-central Pyrenees. Tectonics, 17, 395-406.

Tembe, S., Lockner, D. A., Solum, J. G., Morrow, C., Wong, T.-F., \& Moore, D. E. (2006). Frictional strength of cuttings and core from SAFOD drillhole phases 1 and 2. Geophysical Research Letters, 33, L23307.

Vidal, O., Parra, T., \& Trotet, F. (2001). A Thermodynamic Model for $\mathrm{Fe}-\mathrm{Mg}$ aluminous chlorite using data from phase equilibrium experiments and natural pelitic assemblages in the $100-600^{\circ} \mathrm{C}$, 1-25 kb range. American Journal of Sciences, 301, 557-592.

Vidal, O., Parra, T., \& Vieillard, P. (2005). Thermodynamic properties of the Tschermak solid solution in Fe-chlorite: application to natural examples and possible role of oxidation. American Mineralogist, 90, 347-358.

Viti, C., \& Colettini, C. (2009). Growth and deformation mechanisms of talc along a natural fault: a micro/nanostructural investigation. Contributions to Mineralogy and Petrology, 158, 529-542.

Vrolijk, P., \& Van der Pluijm, B. A. (1999). Clay gouge. Journal of Structural Geology, 21, 1039-1048.

Wintsch, R. P., Christoffersen, R., \& Kronenberg, A. K. (1995). Fluid rock reaction weakening of fault zones. Journal of Geophysical Research, 100, 13021-13032. 